\title{
Classic Polemical Between the novel of Tenggelamnya Kapal Van Der Wijck and Magdalena
}

\author{
Fauzi Rahman*), \\ Universitas Indraprasta PGRI \\ *) Correspondences author: Jl. Raya Tengah No. 80, Kel. Gedong, Kec. Pasar Rebo, Jakarta Timur 13760; Indonesia \\ e-mail: fauzi.rahman@unindra.ac.id
}

\begin{abstract}
This study aims to determine the comparison between the novel Tenggelamnya Kapal van Der Wijck (TKVDW) by Hamka with Magdalena by Al-Manfaluthi. There was a calm question of Hamka's novel which was the result of a copy of the Magdalena. By the method of literary comparison, the results obtained are that indeed in both novels, there are similarities starting from the plot, the detail of the story, and the function of character. However, each story with a different social background ultimately shows its own story, ideas, and social details. Furthermore, regarding the similarity of the story and the rumors of plagiarism by Buya Hamka, there is indeed a plot resemblance, there are thoughts and ideas that remind Magdalena. But the reader must be intelligent and admit that in his narrative in the novel TKVDW, there is a culture of his own, his own experience, as well as his own problems.
\end{abstract}

Key Words: Comparison Study, Adaptation, Hamka, Al Manfaluthi.

Article History: Received: 06/10/2017; Revised: 14/11/2017; Accepted: 19/11/2017; Published: 20/12/2017

How to Cite (MLA $7^{\text {th }}$ ): Rahman, Fauzi. “Classic Polemical Between the novel of Tenggelamnya Kapal Van Der Wijck and Magdalena." Hortatori Jurnal Pendidikan Bahasa dan Sastra Indonesia 1.2 (2017): 108-115. Print/Online. Copyrights Holder: Rahman, Fauzi. First Publication: Hortatori Jurnal Pendidikan Bahasa dan Sastra Indonesia (2017).

\section{Pendahuluan}

Karya sastra merupakan suatu totalitas yang memiliki nilai seni yang dapat dinikmati orang banyak. Karya sastra yang dapat dinikmati oleh para pembaca bisa berbentuk puisi, prosa, dan drama. Akan tetapi, berdasarkan sejarah perkembangan sastra dan minat pembaca di Indonesia, prosa yang berbentuk novel lah yang menjadi primadona sastra dari dulu hingga sekarang.

Tarigan (2011, hlm.164) menerangkan bahwa, "Novel berasal dari kata Latin novellus yang diturunkan pula dari kata novies yang berarti "baru". Dikatakan baru karena jika dibandingkan dengan jenis-jenis sastra lainnya seperti puisi, drama, dan lain-lain, maka jenis novel ini muncul kemudian.

Tentang novel, Kuiper (2012, hlm.1) The novel is a genre of fiction, and fiction may be defined as the art or craft of contriving, through the written word, representations of human life that instruct or divert or both. The various forms that fiction may take are best seen less as a number of separate categories than as a continuum or, more accurately, a cline, with some such brief form as the anecdote at one end of the scale and the longest conceivable novel at the other. Dari definisi menurut Kuiper diatas tentang novel, dikatakan bahwa novel merupakan genre dari fiksi. Fiksi merupakan seni atau kerajinan penuangan melalui kata-kata tertulis yang merupakan representasi dari kehidupan manusia. Novel merupakan sebuah cerita fiksi yang cukup panjang dan biasanya berbentuk sebuah buku.

Pembahasan tentang novel tentu menjadi sebuah kajian yang luas. Salah satu kajian yang dapat digunakan dalam menganalisis novel adalah dengan menggunakan kajian banding atau sastra perbandingan. 
Menurut Henry H Remak (stallnecht dan frenz, 1971, hlm.1) sastra banding adalah studi luar batasan suatu Negara tertentu dan studi tentang hubungan-hubungan antara kesusastraan di satu pihak serta seni-seni dan ilmu-ilmu lain pihak, seperti: seni rupa, seni musik, seni melukis, arsirektur, filsafat, sejarah dan lain-lain. Jadi dapat dikatakan bahwa sastra banding adalah kajian perbandingan antara satu kesusastraan dengan kesusastraan yang lain, atau membanding kesusastraan dengan bidang lain.

Suroso (2009, hlm.94) menjelaskan definisi tentang kajian banding atau sastra banding yaitu, upaya untuk dapat hasil pemahaman makna karya sastra dengan jalan membandingkan dua karya sastra atau lebih yang menunjukkan adanya persamaan dan perbedaan tema, struktur, ataupun gaya.

Selanjutnya, Wellek dan Warren (dalam Yanti dan Zabadi, 2016) menjelaskan, "The history of comparative literature study begins from studies on oral literature, folklore and its migration, that is, how and when it comes into the more artistic literary writing". Sejarah studi komparatif dimulai dari studi sastra lisan, cerita rakyat dan migrasinya, sampai pada penulisan sastra yang lebih artistik. Dalam terminologi ini, literatur komparatif mencakup studi tentang hubungan antara dua literatur atau lebih (Yanti dan Zabadi, 2016).

Berdasarkan hal tersebut maka penulis akan membandingkan Novel Tenggelamnya Kapal Van Der Wijck (TKVDW) Karya Buya Hamka (1938) dengan Novel Magdalena karya Mustafa Luthfi AlManfaluthi (1876). Tenggelamnya kapal Van Der Wijck adalah suatu sastra yang menceritakan budaya, adat Padang yang sangat melekat erat. Magdalena adalah suatu novel yang awalnya berjudul Al-Majdulin, karya Al-Manfaluthi, seorang sastrawan mesir. Al-Majdulin sendiri merupakan sebuah novel terjemahan dari novel Sous Les Tileus karya Alphonse Karr.

Kedua novel ini sama-sama menceritakan tentang perjalanan cinta sepasang pemuda yang dihalangi sebuah tembok besar yang sulit ditembus, pandangan seseorang bahwa cinta saja tidak cukup untuk mengarungi bahtera rumah tangga, dan sebagainya. Kedua novel ini pula menceritakan tentang citacita dan harapan tinggi seorang pemuda yang semasa hidupnya selalu dirundung kemalangan. Akan tetapi karena semangat yang membara akhirnya bisa bangkit dari keterpurukan hingga akhirnya sukses.

Dalam membicarakan tentang perbandingan suatu karya sastra, tidak dapat dilepaskan didalamnya yaitu kajian pengaruh. Kita tidak dapat mengatakan bahwa suatu karya sastra disebabkan oleh karya sastra lainnya. Bisa jadi karya sastra itu tumbuh dari budaya rakyat tersebut.

Tujuan penulisan ini adalah untuk membandingkan jalan cerita dari novel Tenggelamnya Kapal Van Der Wijck dengan novel Magdalena. Selain itu, dibandingkan pula tokoh utama yang diceritakan di dalam kedua novel tersebut, dicari dimanakah kesamaan serta perbedaan yang ada.

Selain tujuan tersebut, pada tahun 1960-an novel TKVDW karya Hamka ini, Abdullah Said Patmadji menuduh Hamka sebagai plagiat. Ini adalah tuduhan yang sangat menyakitkan. Abdullah S.P. menilai TKVDW karya Hamka (1939) merupakan plagiat dari novel Magdalena yang nama awalnya adalah Al-Majdulin. Oleh karena itu penulisan ini juga bertujuan untuk mencoba menjawab pernyataan tersebut.

Pada tahun 2013, novel TKVDW mengilhami sebuah film dengan judul yang sama dan diputar di bioskop seluruh Indonesia, termasuk luar Indonesia. Hal ini tentu saja membangkitkan kembali memori tentang novel serta pengarangnya yang beberapa dekade sebelumnya menjadi perbincangan di kancah kesusastraan Indonesia. Kemunculan kembali novel tersebut dalam bentuk film tentunya akan mengingatkan lagi kasus dugaan plagiasi yang dilakukan oleh Hamka.

\section{Metode}

Metodologi dalam penelitian ini adalah dengan membandingkan persamaan dan perbedaan dalam novel Tenggelamnya Kapal van Der Wijck karya Hamka dengan novel Magdalena karya Mustafa Luthfi El Manfaluthi. Perbandingan ini dilakukan dengan menganalisis persamaan dan perbedaan konten cerita, kemudian menganalisis kesamaan profil dan fungsi tokoh dalam masing-masing novel. Setelah itu, akan dibahas kajian pengaruh dalam kedua novel tersebut sehingga untuk kemudian dapat ditarik sebuah kesimpulan. 


\section{Hasil dan Diskusi}

\section{Perbandingan Profil Tokoh}

Tokoh dalam novel merupakan komponen utama yang menjadi sorotan pembaca. Fungsi tokoh dalam cerita fiksi memiliki peran masing-masing dalam alur sebuah cerita dari awal hingga akhir. Begitupun halnya dalam novel TKVDW dan Magdalena. Tokoh utama dalam novel TKVDW adalah Zainuddin dan Hayati, sedangkan dalam novel Magdalena adalah Stevan dan Magdalena.

Dari jalan cerita kedua novel tersebut, ditemukan ada cukup banyak persamaan baik dari jalan cerita, sifat, dan fungsi para tokoh dalam kedua novel tersebut. Bukan hanya profil tokoh utama, namun hampir seluruh tokoh yang berpengaruh dalam cerita ini memiliki fungsi yang sama. Adapun profil atau fungsi tokoh dalam kedua novel dapat kita identifikasikan sebagai berikut.

Tabel 1

Perbandingan Fungsi Tokoh TKVDW dan Magdalena

\begin{tabular}{llll}
\hline No & \multicolumn{1}{c}{ TKVDW } & \multicolumn{1}{c}{ Magdalena } & \multicolumn{1}{c}{ Fungsi Tokoh } \\
\hline 1 & Zainuddin & Stevan & Tokoh utama laki-laki \\
\hline 2 & Hayati & Magdalena & Tokoh utama perempuan \\
\hline 3 & Mak Base & Ayah Stevan & $\begin{array}{l}\text { Tokoh pengasuh sedari kecil kedua tokoh utama } \\
\text { pria }\end{array}$ \\
\hline 4 & Mamak Datuk & Muller & $\begin{array}{l}\text { Orang tua tokoh utama perempuan yang melarang } \\
\text { dan mengusir tokoh utama laki-laki }\end{array}$ \\
\hline 5 & Khadijah & Suzana & $\begin{array}{l}\text { Sebagai sahabat karib tokoh utama perempuan } \\
\text { yang mempengaruhi tokoh utama }\end{array}$ \\
\hline 6 & Muluk & Fritz & $\begin{array}{l}\text { Sahabat karib tokoh utama pria yang memberikan } \\
\text { semangat kepada tokoh utama }\end{array}$ \\
\hline 7 & Aziz & Edward & $\begin{array}{l}\text { Tokoh laki-laki yang dijodohkan dengan tokoh } \\
\text { utama perempuan }\end{array}$ \\
\hline
\end{tabular}

Meskipun banyak fungsi tokoh yang mirip dan serupa, namun yang menjadi sorotan dalam penceritaan kedua novel ini adalah sosok tokoh utama dalam masing-masing novel. Bagaimana tokoh utama dalam novel memiliki kesamaan yang identik menjadikan hal tersebut menarik untuk dikaji. Adapun persamaan tokoh utama dapat dilihat pada penjelasan berikut.

\section{Persamaan dan perbedaan profil Zainuddin dalam 'TKVDW' dengan Stevan dalam 'Magdalena'}

Terdapat banyak persamaan antara Zainuddin dan Stevan. Persamaan-persamaan tersebut antara lain, keduanya sama-sama seniman, selalu dirundung kemalangan selama hidupnya disebabkan karena tidak memiliki keluarga.

Dalam kesehariannya, darah seniman sudah mengalir pada kedua tokoh itu. Keduanya sama-sama memiliki watak penyabar, setia pada satu pendirian, tidak mudah putus asa walaupun sempat mengalami kegoncangan dalam hidupnya. Keduanya sama-sama mencintai seorang gadis desa, Zainuddin dengan Hayati dalam ceritanya, dan Stevan dengan Magdalena. Cinta kedua tokoh itu kekal sampai ajal mereka datang.

Kedua tokoh itu sama-sama diusir oleh orang tua kekasih mereka. Itu terjadi karena penyebab yang sama, yaitu hubungan mereka diketahui dan tidak direstui oleh orang tua kekasih mereka itu.

Di tengah hubungan cinta mereka dengan kekasihnya masing-masing, keduanya sama-sama dihalangi oleh orang ketiga, Aziz dalam hubungan Zainuddin dengan Hayati, dan Edward dalam hubungan Stevan dengan Magdalena. Pada akhirnya orang ketiga itulah yang berhasil merebut kekasih mereka, bahkan sampai tahap pernikahan.

Kedua tokoh ini sama-sama mendapatkan harta peninggalan dari mendiang keluarganya. Peninggalaan inilah yang membuat keadaan hidup mereka lebih membaik dari sebelumnya. Namun walaupun hidup keduanya membaik setelah mendapatkan warisan itu, keduanya tetap merasa kekurangan karena tidak ada kekasih yang menemani mereka. Karena merasakan kekurangan itulah, kedua tokoh tersebut mengalami keterpurukan yang amat sangat. Di dalam keterpurukan tersebut, keduanya sama-sama 
mendapatkan seorang sahabat yang sangat baik dan sangat setia. Sahaban Zainuddin bernama Muluk, sedangkan sahabat Stevan adalah Fritz. Sahabat mereka itulah yang mengangkat mereka hingga mereka bangkit dan menjadi seorang yang terkenal, sukses dan kaya raya.

Setelah mantan kekasih mereka sama-sama mengalami kemalangan, kemudian sama-sama mencoba kembali meminta harapan pada Zainuddin dan Stevan. Namun mereka menolak mantan kekasih mereka itu karena masih menyimpan dendam dan sakit hati yang mendalam.

Di akhir cerita, kedua tokoh tersebut menyadari bahwa mereka masih sangat menyayangi kekasih mereka itu. Namun semuanya telah terlambat karena kekasih mereka sudah tiada. Zainuddin dan Stevan sama-sama meninggal dunia karena sakit, tak lama setelah kekasih mereka meninggal.

Selain banyak memiliki persamaan, kedua tokoh juga memiliki beberapa perbedaan. Zainuddin diasuh dan dibesarkan oleh pembantu keluarganya yang bernama Mak Base. Sedangkan Stevan dibesarkan oleh ayahnya, ibunya meninggal sejak ia kecil. Namun Stevan melarikan diri dari rumah karena ayahnya tidak mencintainya lagi. Hal ini menyebabkan Stevan seakan-akan tidak memiliki keluarga.

Ketika kedua tokoh tersebut diusir oleh orang tua kekasih mereka, Zainuddin diusir secara halus oleh Datuk, paman Hayati dikarenakan adat istiadat yang melekat dan melarang mereka memiliki hubungan khusus. Sedangkan Stevan diusir oleh Muller, ayah Magdalena karena Stevan adalah orang miskin. Muller menginginkan menantu yang kaya raya dan mempunyai kedudukan tinggi.

Zainuddin sama sekali tidak mengenal Aziz sebagai orang ketiga, sampai ia menyuruh sahabatnya Muluk untuk mencaritahu. Sedangkan Stevan sangat mengenal Edward sebagai orang ketiga dalam hubungannya bersama Magdalena, karena Edward adalah sahabatnya sejak kecil.

Kesuksesan yang yang terjadi pada diri Zainuddin adalah karena bakatnya sebagai seoran penulis. Sedangkan kesuksesan Stevan adalah karena ia berbakat sebagai musisi.

Sebelum kematian Hayati, Zainuddin sempat mengungkapkan kembali cintanya pada Hayati. Sedangkan Stevan tidak sempat menyatakan kembali cintanya karena Magdalena telah tewas bunuh diri dengan menceburkan diri ke sungai.

\section{Persamaan dan perbedaan profil Hayati dalam 'TKVDW' dengan profil Magdalena dalam 'Magdalena'}

Hayati dan Magdalena sama-sama memiliki wajah cantik, keduanya sama-sama terlahir sebagai gadis desa yang lugu dan polos. Keduanya sama-sama memiliki pendirian yang mudah dipengaruhi. Selain itu, kedua tokoh tersebut sama-sama memiliki seorang sahabat, Khadijah sebagai sahabat Hayati, dan Susanna sebagai sahabat Magdalena. Sahabat mereka itulah yang berperan besar dalam mempengaruhi mereka.

Ketika hubungan kedua tokoh tersebut dengan kekasih mereka diketahui oleh orang orang tua mereka yang tidak menyetujui hubungan mereka itu, keduanya sama-sama memohon agar orang tua mereka itu tidak mengusir kekasih yang sangat mereka cintai itu.

Ketika Hayati dengan Zainuddin dan Magdalena dan Stevan berpisah, Hayati dan Megdalena samasama tinggal di perkotaan. Di sanalah keduanya sama-sama menemukan orang ketiga dalam hubungan percintaan mereka. Mereka sama-sama dipengaruhi oleh sahabat-sahabat mereka untuk meninggalkan kekasih mereka dan menyandingkan dengan orang ketiga tersebut. Sampai akhirnya, mereka pun bingung harus memilih siapa. Kemudian sahabat mereka sama-sama terus mempengaruhi Hayati dan Magdalena sampai pada akhirnya hati kedua tokoh tersebut luluh. Mereka pun akhirnya menikah, Hayati dengan Aziz, dan Magdalena dengan Edward. Seketika itu pula keduanya melupakan kekasih mereka sebelumnya.

Ketika membina rumah tangga, keluarga mereka sama-sama mengalami kemerosotan, baik dalam keharmonisan, maupun dalam perekonomian keluarga. Karena kondisi ekonomi keluarga keduanya tidak kunjung membaik, kedua tokoh tersebut bersama suaminy sama-sama menumpang hidup di rumah mantan kekasihnya dulu. Kedua suami mereka sama-sama bunuh diri karena kemiskinan dan keputusasaan.

Kedua tokoh tersebut kemudian sama-sama meminta harapan kembali pada kekasihnya, namun permintaan dan harapan mereka ditolak karena permasalahan sakit hati dan dendam. Setelah itu keduanya sama-sama meninggal dengan tragis.

Dari persamaan-persamaan yang didapatkan, terdapat pula perbedaan-perbedaan. Hayati meninggalkan Zainuddin dan lebih memilih Aziz sebagai suaminya karena alasan adat istiadat yang Hayati tak kuasa menolak desakan tradisi serta desakan keluarganya. Aziz lebih masuk ke dalam adat masyarakat dan keluarganya. Sedangkan Magdalena meninggalkan Stevan karena alasan harta. Stevan dianggap bukan orang berharta dan berkedudukan. Berbeda dengan Edward yang kaya raya dan berpangkat tinggi. 
Hayati bersama Aziz tidak diceritakan memiliki seorang anak bahkan mengandung seorang anak, kendati pun mereka telah beberapa tahun berumah tangga. Sedangkan Magdalena melahirkan seorang bayi tak lama setelah Edward bunuh diri. Bayi perempuan itu kemudian diasuh oleh Stevan.

Sebelum kedua tokoh tersebut meninggal dunia, Hayati sempat bertemu dengan Zainuddin, mendapatkan maaf, dan sempat mendengarkan kembali kata-kata cinta Zainuddin kepadanya walau untuk yang terakhir kalinya. Sedangkan Magdalena tidak sempat bertemu dengan Stevan, belum mendapat maaf dan mendengar kata cinta Stevan kembali, sebelum ia bunuh diri dengan menceburkan diri ke sungai.

\section{Persamaan dan Perbedaan Konten Cerita 'TKVDW' dengan 'Magdalena'}

Kisah yang diceritakan kedua novel hampir sama. Kisah tersebut sama-sama menceritakan seorang pemuda miskin yang tidak memiliki keluarga dan kemudian mencintai seorang gadis desa yang cantik. Keduanya pun sama-sama tidak mendapat persetujuan dari orang tua gadis cantik tersebut. Selain itu, ada beberapa kisah yang kejadiannya persis sama sebagaimana keterangan berikut.

Tabel 2

Persamaan Jalan Cerita Novel TKVDW dan Magdalena

\begin{tabular}{llll}
\hline No & \multicolumn{1}{c}{ Tenggelamnya Kapal van Der Wijck } & \multicolumn{1}{c}{ Magdalena } \\
\hline 1 & $\begin{array}{l}\text { Hayati menyurati Khadijah tentang } \\
\text { kedatangan pemuda Zainuddin (hlm. 35) }\end{array}$ & $\begin{array}{l}\text { Magdalena menyurati Susana tentang } \\
\text { kedatangan pemuda Stevan (hlm. 3-4) }\end{array}$ \\
\hline 2 & $\begin{array}{l}\text { Pertemuan di waktu hujan "di bawah } \\
\text { sebuah payung" disusul dengan perikatan } \\
\text { janji prasetia di sebuah danau (hlm. 47-51) }\end{array}$ & $\begin{array}{l}\text { Perikatan janji prasetia antara Magdalena } \\
\text { dan Stevan "dibawah naungan bunga tilia" } \\
\text { disusul dengan adegan asmara di danau } \\
\text { (hlm. 37-40) }\end{array}$ \\
\hline 3 & $\begin{array}{l}\text { Hubungan asmara antara Hayati dan } \\
\text { Zainuddin tidak disetujui orangtua Hayati } \\
\text { lalu Zainuddin diusir (hlm. 52-56) }\end{array}$ & $\begin{array}{l}\text { Hubungan asmara antara Magdalena dan } \\
\text { Stevan tidak disetujui orangtua Lalu } \\
\text { Stevan diusir (hlm. 52-56) }\end{array}$ \\
\hline 4 & $\begin{array}{l}\text { Khadijah mengecoh Hayati sehingga } \\
\text { membenci Zainuddin (hlm. 83-86) }\end{array}$ & $\begin{array}{l}\text { Susana mengecoh Magdalena sehingga } \\
\text { membenci Stevan(hlm. 115-117) }\end{array}$ \\
\hline 5 & $\begin{array}{l}\text { Perkawinan Hayati dengan Aziz (hlm. } \\
\text { 123-131) }\end{array}$ & $\begin{array}{l}\text { Perkawinan Magdalena dengan Edward } \\
\text { (hlm. 180-190) }\end{array}$ \\
\hline 6 & $\begin{array}{l}\text { Aziz bunuh diri di sebuah hotel di } \\
\text { Banyuwangi (hlm. 175-176) }\end{array}$ & $\begin{array}{l}\text { Edward bunuh diri di sebuah hotel di } \\
\text { Chicago (hlm. 241-243) }\end{array}$ \\
\hline 7 & $\begin{array}{l}\text { Zainuddin mati karena sakit di atas kursi di } \\
\text { depan meja tulisnya (hlm. 198-200) }\end{array}$ & $\begin{array}{l}\text { Stevan mati karena sakit di atas kursi di } \\
\text { depan pianonya (hlm. 280-284) }\end{array}$ \\
\hline 8 & $\begin{array}{l}\text { Zainuddin dikubur di samping Hayati } \\
\text { berdasarkan wasiat Zainuddin. }\end{array}$ & $\begin{array}{l}\text { Stevan dikubur di samping Magdalena } \\
\text { berdasarkan wasiat Stevan. }\end{array}$ \\
\hline
\end{tabular}

Dari Persamaan-persamaan yang ada pada kedua novel tersebut, ditemukan pula banyak perbedaan baik kisah yang terjadi, dari latar waktu, latar, maupun latar kehidupan sosial. Perbedaan-perbedaan itu bisa dilihat pada keterangan berikut.

Tabel 3

Perbedaan Novel TKVDW dengan Magdalena

\begin{tabular}{|c|c|c|}
\hline No & Tenggelamnya Kapal van Der Wijck & Magdalena \\
\hline 1 & $\begin{array}{l}\text { Novel Tenggelamnya Kapal Van der } \\
\text { wijck mengambil latar di tanah minang } \\
\text { desa Batipuh dan Padang Panjang yang } \\
\text { tentu saja dengan adat istiadat yang sangat } \\
\text { kuat. Selain itu juga mengambil seting di } \\
\text { tanah jawa dan makasar. }\end{array}$ & $\begin{array}{l}\text { Novel Magdalena mengambil latar di } \\
\text { daerah bernama Welfath, Koblenz dan } \\
\text { Gutting, dan tentu saja sekaligus } \\
\text { dipengaruhi oleh kebudayaannya. }\end{array}$ \\
\hline 2 & Dilatarbelakangi oleh agama Islam. & Dilatarbelakangi oleh agama Nasrani. \\
\hline 3 & $\begin{array}{l}\text { Pengusiran Zainuddin dikarenakan } \\
\text { permasalahan adat istiadat. Ia seorang } \\
\text { anak dari ayah yang dibuang, meskipun } \\
\text { ayahnya darah minang tulen, tapi } \\
\text { Zainuddin tidak memiliki saudara } \\
\text { perempuan. }\end{array}$ & $\begin{array}{l}\text { Pengusiran Stevan dikarenakan ia orang } \\
\text { miskin yang tidak memiliki masa depan } \\
\text { yang jelas. Jadi pengusirannya karena } \\
\text { pandangan material. }\end{array}$ \\
\hline
\end{tabular}




\begin{tabular}{llll}
\hline 4 & $\begin{array}{l}\text { Zainuddin menjadi kaya raya dan } \\
\text { termahsyur } \\
\text { menulis. }\end{array}$ & $\begin{array}{l}\text { Stevan menjadi kaya raya karena ia } \\
\text { berbakat sebagai musisi. }\end{array}$ & \\
\hline 5 & $\begin{array}{l}\text { Zainuddin dibesarkan oleh Mak Base, } \\
\text { pembantu keluarganya karena ia menjadi } \\
\text { yatim piatu sejak kecil. }\end{array}$ & $\begin{array}{l}\text { Stevan dibesarkan oleh ayahnya, namun } \\
\text { kemudian ayahnya tidak mencintainya lagi } \\
\text { dan akhirnya stevan pergi dan seakan tidak } \\
\text { memiliki keluarga. }\end{array}$ \\
\hline 6 & $\begin{array}{l}\text { Zainuddin mendapat warisan dari Mak } \\
\text { Base }\end{array}$ & $\begin{array}{l}\text { Stevan mendapat warisan dari Almarhum } \\
\text { ayahnya. }\end{array}$ \\
\hline 7 & $\begin{array}{l}\text { Hayati meninggal karena kapal yang } \\
\text { ditumpanginya karam. }\end{array}$ & $\begin{array}{l}\text { Magdalena meningal } \\
\text { menceburkan diri ke sungai yang deras. }\end{array}$ \\
\hline 8 & $\begin{array}{l}\text { Sebelum menghembuskan nafas terakhir, } \\
\text { Hayati bertemu Zainuddin dan mendapat } \\
\text { maaf darinya. }\end{array}$ & $\begin{array}{l}\text { Magdalena belum mendapat maaf dari } \\
\text { Stevan sampai ia meninggal. }\end{array}$ \\
\hline
\end{tabular}

Persamaan dari kedua novel tersebut, sama-sama menceritakan seorang pemuda miskin yang tidak memiliki keluarga mencintai seorang gadis desa yang cantik. Keduanya pun sama-sama tidak mendapat persetujuan dari orang tua gadis cantik tersebut.

Di dalam novel tersebut diceritakan seorang pemuda yang tidak memiliki keluarga, tidak memiliki harta, maupun harta peninggalan dalam hidupnya akan sengsara dalam kemiskinan. Hal ini menerangkan bahwa siapa saja yang tidak memiliki keluarga, dan tidak memiliki harta maka hidupnya akan sengsara dan penuh kemalangan. Kendatipun mendapat kesenangan karena memiliki kekasih seorang gadis cantik, namun tentunya orang tua gadis itu tidak akan setuju dan akan memisahkan anaknya, bagaimanapun caranya.

Kedua novel ini menceritakan orang tua yang tidak setuju apabila anak gadisnya menikah dengan pria yang miskin atau tidak punya masa depan. Ini menerangkan bahwa orang tua manapun tentunya menginginkan yang terbaik bagi putri tercintanya. Orang tua tidak mau hanya karena alasan cinta, putrinya mengambil resiko hidup sengsara apabila menikah dengan pria yang miskin atau tidak punya kedudukan.

Di dalam cerita kedua novel, dikisahkan seorang gadis bisa saja lebih tertarik kepada pria yang dianggap bisa lebih menjamin kehidupannya kelak apabila menjadi suami. Ini terjadi pada tokoh Hayati dan Magdalena. Hayati yang tertekan adat dan keluarga, ditambah pula bayangan-bayangan keindahan dan kemegahan apabila menikah dengan Aziz, juga Magdalena yang tertarik pada kegagahan Edward dan kedudukan Edward yang tinggi hingga ia meninggalkan Stevan. Secara tidak langsung cerita tersebut menyiratkan bahwa cinta saja tidak akan cukup untuk menjamin keawetan dalam hubungan sepasang kekasih sebelum memasuki jenjang pernikahan, karena dalam memasuki bahtera rumah tangga memerlukan persiapan baik itu mental maupun material.

\section{Apakah Hamka Plagiat? Sebuah Polemik Klasik}

Tahun 1962 adalah tahun yang berat bagi Buya Hamka. Sebab, pada September 1962, novel Tenggelamnya Kapal van Der Wijck dalam edisi bahasa Indonesia itu dinilai merupakan novel saduran dari novel Sous les Tilleuls (Di Bawah Pohon Tilia) karya sastrawan Prancis, Alphonse Karr. Tuduhan ini dilontarkan oleh seorang kritikus bernama Abdullah Said Pamudji dengan tulisannya yang bertajuk Aku Mendakwa Hamka Plagiat.

Kritikus sastra H.B. Jassin menolak tuduhan itu. Menurut Jassin yang disebut "plagiat" itu adalah pengambilan karangan orang lain sebagian atau seluruhnya dan membubuhkan nama sendiri seolah-olah kepunyaannya. Di samping "plagiat", ada saduran, yaitu karangan yang jalan ceritanya dan bahan-bahannya diambil dari suatu karangan lain, misalnya cerita luar negeri disesuaikan dengan alam sendiri (Indonesia) dengan mengubah nama-nama dan suasananya. Saduran itu pun harus disebutkan nama pengarang aslinya. Selain "plagiat" dan "saduran", ada juga "pengaruh", yakni hasil ciptaan pengarang sendiri mendapat pengaruh pikiran atau filsafat pengarang lain, baik disengaja maupun tidak.

Dalam hal roman Hamka itu, H.B. Jassin mengatakan bahwa karya itu bukan plagiat atau jiplakan, karena Hamka tidak hanya menerjemahkan dan membubuhkan nama sendiri dalam terjemahan itu, melainkan menurut Jassin, lebih tepat Hamka mengadaptasi karya Manfaluthi tersebut. Hamka menggunakan pola dan plot yang ada dalam karya Manfaluthi, tetapi ia mengisi tema dan idenya sendiri. Hamka sangat terpengaruh Manfaluthi sehingga menyenangi dan menggunakan hal-hal yang sama dengan 
Manfaluthi, termasuk cara pengucapannya. Hal ini mungkin karena keaslian pengucapan belum menjadi mode pada masanya.

Sebenarnya, tidak ada yang pasti atas jawaban dari pertanyaan, "Apakah Hamka memplagiasi Al Majdulin (Magdalena)?". Pada tahun 2008, dalam sebuah kuliah terbuka di Universitas Muhammadiyah Prof. Dr. HAMKA, Putri Alm. Buya Hamka, Prof. Dr. Hj. Aliyah Hamka (Alm.) mendapat pertanyaan tentang apakah ayahandanya mempalgiat karya Al Manfaluthi. Namun, beliau sendiri tidak pernah mengetahui dan tidak pula mendapatkan jawaban langsung dari ayahnya terkait pertanyaan tersebut. Jika saja beliau yang notabene anak kandungnya tidak mengetahui jawaban yang pasti, tentunya kita sebagai pembaca yang hanya bisa menilai, pada akhirnya hanya akan menilai kasus ini dari unsur subjektivitas masing-masing.

\section{Simpulan}

Dalam adat mingkabau, seorang pria yang tidak jelas asal usulnya, meskipun ia baik hati namun tidak pantas untuk mencari istri seorang gadis minang tulen. Inilah yang menyebabkan awal terjadinya pengusiran Zainuddin oleh keluarga Hayati. Zainuddin dianggap orang lain, karena meskipun ayahnya seorang Minang tulen, tapi ibunya orang lain. Dalam adat minang, wanita merupakan tokoh penting. Karena seorang pria yang tidak memiliki saudara wanita tidak akan mendapatkan harta warisan sedikitpun. Oleh karena itu lah Zainuddin dianggap orang lain.

Berbeda dengan cerita dalam novel Magdalena. Stevan diusir oleh Ayah Magdalena karena ia seorang pria miskin yang tidak akan bisa memberikan kebahagiaan kepada Magdalena. Dalam budaya yang ada dalam novel Magdalena itu, nampaknya faktor materialistis sudah menjadi tolok ukur pertama seseorang dalam memilah-milah calon keluarga.

Jika melihat pada pendapat dua kritikus sastra di atas, H.B. Jassin cenderung membela Hamka dan membuat simpulan bahwa Hamka melakukan adaptasi cerita. Hal ini tentunya tidak terlepas dari kedekatan H.B. Jassin dengan Hamka yang memang berada pada satu visi. Hamka dan H.B. Jassin berada organisasi yang sama, yaitu organisasi Pujangga Baru. Sedangkan, Abdullah Said Pamuji memilih simpulan bahwa Hamka melakukan plagiasi tentunya tidak terlepas dari subjektivitas Abdullah sebagai seorang kritikus. Pada saat yang sama, Abdullah Said Pamuji berada pada kubu yang berseberangan dengan Hamka dan Jassin, yaitu pada organisasi Lembaga Kebudayaan Rakyat (Lekra). Jika kita membaca rujukan tentang sejarah sastra Indonesia, maka kita dapat melihat bahwa antara Pujangga Baru dengan Lekra memang memiliki misi dan visi yang bertolak belakang. Pujangga Baru yang merupakan organisasi penyair serta sastrawan yang berideologi nasionalis, bahkan beberapa di antaranya adalah agamis. Hal ini menjadikan Pujangga Baru bertolak belakang dengan Lekra yang di dalamnya terdapat sastrawan-sastrawan dengan ideologi sosialis.

Selanjutnya, mengenai kemiripan cerita dan desas-desus mengenai plagiasi yang dilakukan oleh Buya Hamka, memang ada kemiripan plot, ada pikiran-pikiran dan gagasan-gagasan yang mengingatkan kepada Magdalena. Akan tetapi pembaca harus cerdas dan mengakui bahwa dalam penceritaannya dalam novel TKVDW, ada pengungkapan sendiri, pengalaman sendiri, permasalahan sendiri. Sekiranya ada niat pada Hamka untuk menyadur Magdalena-Manfaluthi, kepandaiannya melukiskan lingkungan masyarakat dan menggambarkan alam serta manusianya, kemahirannya melukiskan seluk-beluk adat istiadat serta keahliannya membentangkan latar belakang sejarah masyarakat Islam di Minangkabau, mengangkat ceritanya itu jadi ciptaan Hamka sendiri. Pengalaman sendiri dan pengungkapan sendiri dari Hamka itu demikian kuat. Oleh karena itu, simpulan tentang apakah karya Hamka ini merupakan plagiat atau bukan, semuanya dikembalikan kepada pembaca.

\section{Ucapan Terima Kasih}

Terima kasih kepada semua pihak yang membantu penulis dalam menyelesaikan penelitian ini. Penulis ucapkan terima kasih kepada editor Hortatori. 


\section{Daftar Rujukan}

Al-Manfaluthi, M. L. (2000). Magdalena. Jakarta: NUUN (Navila Group). 2000. Print.

Hamka, B. Tenggelamnya Kapal van der Wijck. Jakarta: Pustaka Antara. 1987. Print.

Kuiper, K. Prose: LiteraryTerms and Concepts. New York: Britannica Educational Publishing. 2012. Print.

Stallnecht, N. P. and Franz, H. Comtemporery Literature: Method and Perspective. Carbondale and Edwardsville: Illionis University Press. 1971. Print.

Suroso, dkk. Kritik Sastra: Teori, Metodologi, dan Aplikasi. Yogyakarta: Elmatera Publishing. 2009. Print. Tarigan H. G. Prinsip-prinsip Dasar Sastra. Bandung: Angkasa. 2011. Print.

Yanti, P. G. Diktat Sastra Banding. Jakarta: FKIP UHAMKA. 2010. Print.

Yanti, P. G. \& Zabadi, F (2016) A Comparative Study of Indonesian Fairytales Structure. Rupkatha Journal on Interdisciplinary Studies in Humanities, Vol. VIII, No. 3, 2016 0975-2935 DOI: http://dx.doi.org/10.21659/rupkatha.v8n3.26. 